\title{
CAN DIETARY DRIED OREGANO IMPROVE THE DIGESTIBLE NUTRIENT INTAKE OF GROWING GOATS?
}

\section{¿PUEDE EL OREGANO SECO DIETARIO MEJORAR EL CONSUMO DE NUTRIENTES DIGESTIBLES EN CABRITOS EN CRECIMIENTO?}

\author{
Pamela Williams ${ }^{1 *}$, Ximena Cifuentes ${ }^{1}$, Valeria Velasco ${ }^{1}$, Jorge Campos ${ }^{1}$, Fernando Bórquez ${ }^{1}$, \\ Rodrigo Allende ${ }^{2}$
}

${ }^{1}$ Facultad de Agronomía, Depto. Producción Animal, Universidad de Concepción, Avda. Vicente Méndez 595, Chillán, Chile.

${ }^{2}$ Facultad de Ciencias Veterinarias, Depto. Ciencias Pecuarias, Universidad de Concepción, Avda. Vicente Méndez 595, Chillan, Chile.

"Corresponding author: pamelawilliams@udec.cl

\begin{abstract}
The aim of this study was to evaluate the effect of dietary dried oregano on the intake of dry matter and digestible nutrients in growing goats. Fifteen 7 -month old male goats were fed on diets with 0,10 and $50 \mathrm{~g} \mathrm{~kg}^{-1}$ of dried oregano based on dry matter (DM). A completely randomized design was used, and each animal was assigned to one pen and treatment ( 3 treatments $\times 5$ replicates) for 45 days. Voluntary intake of DM and nutrient digestibility were measured using acid insoluble ash as an indigestible marker. Daily weight gains were 146,126 and $122 \mathrm{~g} \mathrm{~d}^{-1}$ per treatment $(P=0.08)$. A positive effect on digestible nutrient intake was obtained with both oregano concentrations. Linear and quadratic effects were obtained in the digestible neutral detergent fibre (NDF) and the other nutrient intakes, respectively. No effect was observed in DM or digestible acid detergent fibre (ADF) intakes. Therefore, there was a positive effect on the coefficient of DM in both treatments and NDF digestibility in the treatment with the highest concentration of dietary dried oregano. The positive effect of dried oregano on the goats' diet in terms of digestible nutrient intake suggests that oregano essential oil (EO) modifies the ruminal microflora by improving digestibility, rather than having an effect on the feeding behavior of the animal due to the flavour of the diet. The treatment containing $10 \mathrm{~g} \mathrm{~kg}^{-1}$ of dietary dried oregano promoted voluntary DM consumption and increased the intake of digestible nutrients, while that containing $50 \mathrm{~g} \mathrm{~kg}^{-1}$ of dried oregano only promoted the intake of digestible NDF.
\end{abstract}

Key words: Capra hircus, digestibility, Origanum vulgare, sensory specific satiety

\section{RESUMEN}

El objetivo de este estudio fue evaluar el efecto del orégano seco dietario sobre el consumo de materia seca y de nutrientes digestible en caprinos en crecimiento. Los animales de 7 meses de edad, recibieron dietas con 0,10 y $50 \mathrm{~g} \mathrm{~kg}^{-1}$ de orégano seco en base materia seca (MS). Cada animal fue asignado a un corral y tratamiento ( 3 tratamientos $x 5$ repeticiones) por 45 días. El consumo voluntario de MS y la digestibilidad de nutrientes fue medida usando ceniza insoluble en ácido como marcador

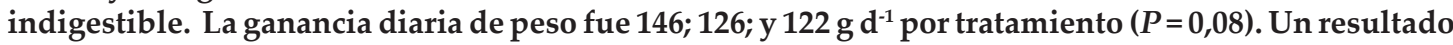
positivo en el consumo de nutrientes digestibles fue obtenido con ambas concentraciones de orégano. Un efecto lineal y cuadrático fue obtenido para consumo de fibra detergente neutra digestible (FDN)

Received: 16 August 2017. Accepted: 03 October 2017 
y consumo de otros nutrientes, respectivamente. No se observó efecto en el consumo de MS ni de fibra detergente ácida (FDA) digestible. Sin embargo, se encontró un efecto positivo en el coeficiente de digestibilidad de MS en ambos tratamientos y de digestibilidad de FDN para el tratamiento con mayor concentración de orégano. El resultado positivo del orégano seco en las dietas de caprinos en el consumo de nutrientes digestibles, sugiere que los aceites esenciales de orégano modifican la microflora ruminal, mejorando la digestibilidad, más que teniendo un efecto en el comportamiento alimenticio del animal debido al flavor de la dieta. El tratamiento con $10 \mathrm{~g} \mathrm{~kg}^{-1}$ de orégano seco dietario, tendió a promover el consumo de MS y aumentó el consumo de nutrientes digestibles. La dieta con $50 \mathrm{~g} \mathrm{~kg}^{-1}$ de orégano seco solo promovió el consumo de FDN digestible.

Palabras clave: Capra hircus, digestibilidad, Origanum vulgare, saciedad sensorial especifica.

\section{INTRODUCTION}

Changes in the characteristics of feeds, such as odour, taste or visual presentation, affect dry matter (DM) intake of ruminants (Favreau-Peigne et al., 2013) and, in turn, the supply of nutrients to the gut of the animal. Digestibility, as an indicator of the degree of disappearance of nutrients contained in the food through the gastrointestinal tract (Pacheco and Waghorn, 2008), is used to estimate the intake of digestible nutrients.

Manipulation of the rumen microbial population through the use of additives can be used to inhibit or modulate the activity of microbial species involved in the digestion of nutrients in the rumen (Cieslak et al., 2013), increasing the amount of fermented nutrients, changing the volatile fatty acids (VFA) profile, and maximising the efficiency of microbial protein synthesis (Tedeschi et al., 2011; Bodas et al., 2012). Furthermore, some additives have been used to minimise both ammonia accumulation and methane production in the rumen (Tedeschi et al., 2011).

Traditionally, antibiotics have been included in diets as growth promoters at sub-clinical doses with the risk of creating resistance to antibiotics used in human therapy (Jouany and Morgavi, 2007). Nowadays, consumers and different government agencies want to eliminate the use of these animal husbandry practices, leading to more restrictive food regulations in Europe (Official Journal of the European Union, 2003). This situation has given rise to the study of some plant extracts as natural alternatives to chemical antibiotic growth promoters (Bampidis et al., 2005; Spanghero et al., 2008).

The essential oil (EO) of oregano (Origanum vulgare L.) has a great potential as an additive in ruminant diets due to its antimicrobial, antioxidant and anti-mutagenic activity (Bampidis et al., 2005; Bodas et al., 2012). The main active components of oregano $\mathrm{EO}$ are the monoterpenes, carvacrol and thymol (Bampidis et al., 2005) which represent 50 and $30 \%$ of its composition, respectively (Bakkali et al., 2008). Carvacrol and thymol have antiseptic properties because they cause disruption of the bacterial membrane, coagulating the cytoplasm and damaging lipids and proteins (Bampidis et al., 2005; Bakkali et al., 2008). In vitro studies have shown an increase in the efficiency of ruminal metabolism since the EO would have a selective effect on the rumen microflora, increasing the digestibility of the diet and promoting animal growth (Calsamiglia et al., 2007). However, Chaves et al. (2008) indicated that carvacrol at a dose of $0.2 \mathrm{~g} \mathrm{~kg}^{-1} \mathrm{DM}$ as an additive in the diet of lamb did not modify DM intake or live weight (LW) gain $(P>0.05)$. In vivo studies have been conducted in order to evaluate the effect of the inclusion of EO in the diets of broilers (Pirgozliev et al., 2015), pigs (Lan et al., 2016) and sheep (Bampidis et al., 2005, Chaves et al., 2008; Simitzis et al., 2008). The inclusion of EO did not have a positive effect in all the studies, which can be probably explained by the use of low concentrations. Furthermore, no studies have been conducted on the use of oregano essential oils in goats, which is particularly interesting if we consider that they exhibit selective consumption behaviour.

The hypothesis of this work is that dietary dry oregano improves digestible nutrients intake. The aim of this study was to evaluate the effect of the inclusion of dried oregano in goats' diets on dry matter and digestible nutrient intakes.

\section{MATERIALS AND METHODS}

The trial was conducted in Chillán (36³4' S; 74ํㅜㄴ $\mathrm{W})$, Biobio Region, Chile, between June and November of 2007. The approval of the Bioethics Committee of the School of Veterinary Sciences, Universidad de Concepcion, was obtained to carry out this research. Fifteen Creole $x$ Boer entire growing goats $(7 \pm 1$ month old $)$ were allocated to individual pens of $1.3 \times 2.1$ $\mathrm{m}$, with individual feeders, water bowls and bedding of wheat straw. The experiment was a completely randomised design, and each animal 
was assigned to one pen and treatment. A total mix ration using ryegrass (Lollium perenne) hay, grounded lupin and grounded whole maize was formulated as a control diet. The trial included a control group $(n=5$; initial live weight $L W=$ $24,3 \mathrm{~kg}$ ), and two treatments with two contrasting concentrations of oregano to prospect, which were higher than those reported by literature (Bampidis et al., 2005): $10 \mathrm{~g} \mathrm{~kg}^{-1}(\mathrm{n}=5$; initial $\mathrm{LW}=$ $24.7 \mathrm{~kg})$ and $50 \mathrm{~g} \mathrm{~kg}^{-1}(\mathrm{n}=5$; initial $\mathrm{LW}=23.7 \mathrm{~kg})$ of dried oregano, on a DM basis $(\mathrm{P}=0.85)$. The animals were weighed at the beginning and the end of the trial. Isonitrogenous and isocaloric diets were formulated according to the nutritional requirements of goats (NRC, 1981), and the ration was adjusted according to changes in live weight (LW) of the animals during the study. The nutritional composition of oregano and of the diets is shown in Table 1. The animals were fed twice a day, $60 / 40 \%$ of the ration morning/ afternoon in order to stimulate feed consumption. Water was available ad libitum during the study.

The study lasted for 62 days, with a $17 \mathrm{~d}$ period of adaptation to housing conditions in which animals were fed with ryegrass (Lollium perenne) hay, twice a day. During the last 45 days, diets including oregano were offered to the animals and feed intake was recorded. The food intake was calculated by weight differences of food offered and rejected. In vivo digestibility trials were carried out the last 4 weeks. Total faeces were collected during 3 consecutive days, using a collection harness; samples were taken in the morning on a daily basis, collected in sealable plastic bags and then frozen. These were processed as composite samples per animal per week, and chemically analysed. Acid insoluble ash (AIA) was used as a natural marker to evaluate the digestibility of diets by analysing its concentration in different diets and faeces (Van Keulen and Young, 1977). The digestibility of DM and nutrients was calculated as follow: DM digestibility $(\%)=[1-(\mathrm{MC} / \mathrm{FM})]^{*} 100$, and Nutrient digestibility $(\%)=1-(\mathrm{MC} / \mathrm{FM}) *(\mathrm{FN}$ $/ \mathrm{DN}) * 100$, where $\mathrm{MC}$ indicates concentration of the marker in the diet; FM corresponds to the concentration of the marker in the faeces; FN denotes the concentration of the nutrient in the faeces; and DN indicates the concentration of nutrient in the diet. Dry matter and nutrient digestibility were calculated by multiplying the DM content by the nutrient digestibility coefficient.

The total mixed diets, oregano and faeces were chemically analysed in the Laboratory of Animal Nutrition, Universidad de Concepción. Dry matter, total ash (TA), crude protein $(\mathrm{CP})$ and ether extract (EE) were determined according to AOAC procedures (AOAC, 1997). Neutraldetergent fibre (NDF) was determined using the method of Van Soest et al. (1991). Acid-detergent fibre (ADF) was determined using the method

Table 1. Diets and their nutritional composition on dry matter basis (DMB)

\begin{tabular}{|c|c|c|c|c|}
\hline & \multicolumn{3}{|c|}{ Composition of the diet $\left(\mathrm{g} \mathrm{kg}^{-1}\right)$} & \\
\hline & Control & $\begin{array}{c}10 \mathrm{~g} \mathrm{~kg}^{-1} \\
\text { dietary dried } \\
\text { oregano DMB }\end{array}$ & $\begin{array}{c}50 \mathrm{~g} \mathrm{~kg}^{-1} \\
\text { dietary dried } \\
\text { oregano DMB }\end{array}$ & \\
\hline Ryegrass hay & 670 & 670 & 640 & \\
\hline Whole corn & 170 & 160 & 150 & \\
\hline Ground lupine & 160 & 160 & 160 & \\
\hline \multirow[t]{3}{*}{ Dried oregano } & 0 & 10 & 50 & \\
\hline & \multicolumn{4}{|c|}{ Nutritional composition of diets and oregano $\left(\mathrm{g} \mathrm{kg}^{-1}\right)$} \\
\hline & Control & \begin{tabular}{l}
\multicolumn{1}{c}{$10 \mathrm{~g} \mathrm{~kg}^{-1}$} \\
dietary dried \\
oregano DMB
\end{tabular} & $\begin{array}{l}50 \mathrm{~g} \mathrm{~kg}^{-1} \\
\text { dietary dried } \\
\text { oregano DMB }\end{array}$ & $\begin{array}{l}\text { Pure } \\
\text { dried } \\
\text { oregano } \\
\text { DMB }\end{array}$ \\
\hline Dry matter & 863 & 865 & 865 & 858 \\
\hline Ash & 60 & 64 & 67 & 91 \\
\hline Crude protein & 113 & 120 & 122 & 111 \\
\hline Ether extract & 26 & 25 & 25 & 42 \\
\hline Metabolizable energy Mcal kg-1 & 2.2 & 2.2 & 2.2 & 2.5 \\
\hline Neutral- detergent fibre & 586 & 523 & 590 & 324 \\
\hline Acid- detergent fibre & 331 & 337 & 341 & 240 \\
\hline
\end{tabular}


973.18 of AOAC (1996). Acid insoluble ash (AIA) was determined using $2.5 \mathrm{~g}$ of sample, which was burned at $500^{\circ} \mathrm{C}$ for $5 \mathrm{~h}$, and then boiled in $25 \mathrm{~mL}$ of $10 \% \mathrm{HCl}$ for $5 \mathrm{~min}$ and filtered. Subsequently, the residue was calcined at $550^{\circ} \mathrm{C}$ and the sample was finally weighed (Van Keulen and Young, 1977). The metabolisable energy (ME) was calculated using the formula given by Marble (1984).

Repeated measures were used to analyse feed intake digestibility, and daily live weight gain. The data were analysed using the MIXED procedure of SAS software 8 (SAS, 1999). The model included the fixed effects of treatment (dried oregano), time, and treatment $x$ time interactions. Each goat was used as an experimental unit for statistical analysis. The minimum values of Akaike's information criterion were used to select the covariance structure among compound symmetry, heterogeneous compound symmetry, autoregressive and heterogeneous autoregressive. Orthogonal polynomial contrasts were carried out to test for linear and quadratic responses on the daily digestible intake of DM, NDF, ADF and protein, as well as daily metabolisable energy intake due to increasing concentrations of dried oregano in the diet.

\section{RESULTS AND DISCUSSION}

No effect on dry matter intake of feed was observed in goats fed with 10 or $50 \mathrm{~g} \mathrm{~kg}^{-1}$ of oregano as part of the $\mathrm{DM}(P=0.10)$ as shown in Table 2. However, the inclusion of dried oregano in the diets of growing goats had a positive effect on digestible intake in terms of all the other parameters evaluated, with the exception of digestible ADF intake (Table 2).

Dry matter intake did not show a positive linear effect due to the inclusion of dried oregano in the goats' diet. Instead, the effect tended $(P=$ $0.06)$ to be quadratic, with no interaction between treatment and time. Only digestible NDF intake showed a linear effect due to the inclusion of dried oregano in the goats' diet in both concentrations. A positive quadratic relationship was observed in digestible $\mathrm{DM}$, digestible $\mathrm{CP}$ and ME intakes. The positive effect of dried oregano on DM and digestible DM intake may be due to an acceptable taste and odour. However, when oregano was

Table 2. Dry matter (DM) and digestible nutrient intake (as metabolic live weight unit) including 10 and $50 \mathrm{~g} \mathrm{~kg}^{-1}$ (DM Basis) dried oregano in the diets of growing goats.

\begin{tabular}{|c|c|c|c|c|c|c|c|c|}
\hline & \multirow[t]{2}{*}{ Unit } & \multicolumn{3}{|c|}{$\begin{array}{c}\text { Dietary dried } \\
\text { oregano } \\
\left(\mathrm{g} \mathrm{kg}^{-1} \mathrm{DM}\right)\end{array}$} & \multirow[t]{2}{*}{ SEM } & \multirow[b]{2}{*}{$P$} & \multicolumn{2}{|c|}{$P$-values } \\
\hline & & 0 & 10 & 50 & & & $L$ & $Q$ \\
\hline DM intake & $\mathrm{g} \mathrm{kg}^{0.75} \mathrm{~d}^{-1}$ & $87.09^{a b}$ & $93.58^{a}$ & $79.40^{b}$ & 1.66 & 0.103 & 0.180 & 0.060 \\
\hline $\begin{array}{l}\text { Digestible DM } \\
\text { intake }\end{array}$ & $\mathrm{g} \mathrm{kg}^{0.75} \mathrm{~d}^{-1}$ & $54.47^{\mathrm{b}}$ & $63.89^{a}$ & $57.24^{b}$ & 1.47 & 0.002 & 0.260 & 0.001 \\
\hline $\begin{array}{l}\text { Digestible crude } \\
\text { protein intake }\end{array}$ & $\mathrm{g} \mathrm{kg}^{0.75} \mathrm{~d}^{-1}$ & $8.87^{b}$ & $10.25^{a}$ & $8.59^{b}$ & 0.23 & 0.021 & 0.510 & 0.001 \\
\hline $\begin{array}{l}\text { Digestible neutral } \\
\text { detergent fibre } \\
\text { intake }\end{array}$ & $\mathrm{g} \mathrm{kg}^{0.75} \mathrm{~d}^{-1}$ & $21.83^{\mathrm{b}}$ & $25.02^{a}$ & $25.71^{a}$ & 0.48 & 0.002 & 0.001 & 0.210 \\
\hline $\begin{array}{l}\text { Digestible acid } \\
\text { detergent } \\
\text { fibre intake }\end{array}$ & $\mathrm{g} \mathrm{kg}^{0.75} \mathrm{~d}^{-1}$ & 12.89 & 13.91 & 13.61 & 0.28 & 0.260 & 0.260 & 0.260 \\
\hline $\begin{array}{l}\text { Metabolisable } \\
\text { energy intake }\end{array}$ & Kcal kg ${ }^{0.75} \mathrm{~d}^{-1}$ & $192.77^{b}$ & $222.77^{\mathrm{a}}$ & $185.95^{b}$ & 4.88 & 0.002 & 0.460 & 0.000 \\
\hline
\end{tabular}

a, b, c Mean values in the same row with a different letter differ by least square linear hypothesis test $(P \leq 0.05)$.

SEM: standard error of the mean 
used at a higher rate $\left(50 \mathrm{~g} \mathrm{~kg}^{-1}\right)$, it resulted in a reduced intake of both DM and digestible DM; values observed were lower at the lowest dose of oregano, but similar to the control.

A study in lambs conducted by Simitzis et al. (2008) found no effects with the use of dietary oregano EO supplementation $\left(1 \mathrm{~g} \mathrm{~kg}^{-1}\right.$ as feed), except during the first 2-3 days. The treated group of lambs seemed to eat smaller quantities of feed compared to the control group whose diet included no oregano EO. Other studies in lambs using pure carvacrol and cinnamaldehyde at concentrations of $0.2 \mathrm{~g} \mathrm{~kg}^{-1}$ of DM offered, reported no effects on the food intake (Chaves et al., 2008). Similar results were obtained by Bampidis et al. (2005) in lambs fed on diets with oregano at concentrations of 4 and $8 \mathrm{~g} \mathrm{~kg}^{-1}$ of DM. This indicates that the negative effects on voluntary intake would be observed using levels above $20 \mathrm{~g} \mathrm{~kg}^{-1}$. In present study, the negative effect occurred with a higher content of dried oregano in the diet, which can be explained by the lower concentration of EO present in the oregano rather than the concentration used..

The results also showed that the lower concentration of dried oregano increased consumption of digestible nutrients, but increasing the concentration of oregano depressed intake. This could be explained by the saturation of the animal senses with the smell, producing what is known as "sensory-specific satiety". This argument was also used by Simitzis et al. (2008) for lambs supplemented with $1 \mathrm{~mL} \mathrm{~kg}^{-1}$ oregano essential oil. With increasing concentrations of feed additive, the initial positive effect would decrease, reducing voluntary intake (Rolls, 1986), or may cause "aversion", which results in the animal eating less of that food (Provenza, 1996). Otherwise, the voluntary food consumption might be stimulated (Early and Provenza, 1998). This concept may be considered to be bi-phase, the first when an increase in the digestibility of the nutrients limits consumption, and the second when the presence of oregano $\mathrm{EO}$ at ruminal level could lead to a toxic effect.

The use of dietary oregano promoted an increase in voluntary intake of metabolisable energy, with no interaction with the time of evaluation (Table 2). The increase of metabolisable energy intake seems to be due to the influence of the EO on digestibility, which supports the first theory proposed by Early and Provenza (1998). Bampidis et al. (2005) did not observe any effects on digestible nutrients in lambs using a lower concentration of oregano than in the present study. Nevertheless, they found a positive effect on the digestibility coefficient of NDF. This could be explained by the increase in the digestibility of the diet due to selective inhibition of rumen microbial population by oregano EO. This action could produce a positive effect on propionate production, reducing energy losses by decreasing $\mathrm{CH}_{4}$ and $\mathrm{CO}_{2}$ production (Tedeschi et al., 2011; Bodas et al., 2012).

Hristov et al. (2013) obtained opposite results in dairy cows and found that digestibility of NDF decreased when fresh oregano was incorporated in the diet at concentrations of $0.35 ; 0.7$; and 0.98 $\mathrm{g} \mathrm{kg}^{-1}$ of LW, without affecting digestibility of other nutrients. Moreover, they indicated that the presence of the bacterial species Ruminococcus flavefaciens slightly increased in the rumen when a low concentration of oregano was used, but decreased when increasing the amount of oregano (quadratic effect) in the diet. This species of bacteria is one of the largest rumen fibrolytic species, and might have caused the increase in the digestibility of NDF.

The oregano concentration intake of $0.57 \mathrm{~g}$ $\mathrm{kg}^{-1}$ of LW was between low and intermediate concentrations, while that of $2.7 \mathrm{~g} \mathrm{~kg}^{-1}$ of $\mathrm{LW}$ doubled the maximum value reported by Hristov et al. (2013). In addition, an increase in the intake of digestible protein implies an increase in the availability of metabolisable protein and amino acids in the animal, with positive effects on growth, implying an increase in the efficiency of nitrogen use. However, this effect was not observed in the present study. The effect of EO, such as thymol, eugenol, and limonene, among others, on the efficiency of the utilisation of ingested nitrogen is related to the inhibition of the growth and the activity of microorganisms. Clostridium sticklandii and Peptostreptococcus anaerobius are considered ammonium hyper-producers (Tsiplakou et al., 2017), causing an increase of the live weight of the animal. Moreover, EO rich in thymol affects proteolysis in the rumen due to the probable toxicity of some species of bacteria, protozoa and fungi present in the rumen, inhibiting proteolysis and the degradation of fibres (Tedeschi et al., 2011; Cieslak et al., 2013). These considerations are important and the concentration of plant extracts and/or EO should be included in the diets. In the present study, the positive effect of dried oregano on the digestible NDF suggests that the concentrations used were not toxic to fibrolytic species. It could be thought that dietary dried oregano was included in the diet with an optimum value close to $5 \%$ of the DM offered (Table 2).

No effects were observed in live weight gain. Daily live weight gains of the goats were $146 \mathrm{~g}$ $\mathrm{d}^{-1}$ in the control, $126 \mathrm{~g} \mathrm{~d}^{-1}$ with $10 \mathrm{~g} \mathrm{~kg}^{-1} \mathrm{DM}$, and $122 \mathrm{~g} \mathrm{~d}^{-1}$ with $50 \mathrm{~g} \mathrm{~kg}^{-1} \mathrm{DM}$, which were not different from each other $(P=0.08)$, while 
final live weight was 30.9 ; 30.4; and $30.1 \mathrm{~kg}$ per treatment, respectively $(P=0.77)$. Therefore, the inclusion of dried oregano in the goats' diet had no effect on animal weight.

\section{CONCLUSION}

The inclusion of dried oregano in the diet of growing goats increases the digestibility of nutrients with no effect on live weight gain. This effect was evident in all the parameters analysed, except digestible ADF intake. The inclusion of $50 \mathrm{~g} \mathrm{~kg}^{-1}$ of oregano in the diet only stimulated consumption of the digestible neutral-detergent fibre fraction. Dried oregano at the concentration used in this study does not act as a natural growth promoter.

\section{ACKNOWLEDGEMENTS}

We would like to thank the Clinical Laboratory Someruno S.A and Mr. Armando Rodríguez Toro for the financial contribution to this study.

\section{LITERATURE CITED}

AOAC. 1997. Official methods of analysis. Association of Official Analytical Chemistry (AOAC). Vol. 2 (16th. ed.). Arlington, Virginia, USA.

Bakkali, F., S. Averbeck, D. Averbeck, and M. Idaomar. 2008. Biological effects of essential oils - a review. Food Chem. Toxicol. 46:446475.

Bampidis, V.A, V. Christodoulou, P. Florou-Paneri, E. Christaki, A.B Spais, and P.S Chatzopoulou. 2005. Effect of dietary dried oregano leaves supplementation on performance and carcass characteristics of growing lambs. Anim. Feed Sci. Technol. 121:285-295.

Bodas, R., N. Prieto, R. García-González, S. Andrés, F.J. Giráldez, and S. López. 2012 Manipulation of rumen fermentation and methane production with plant secondary metabolites. Anim. Feed Sci. Technol. 176:7893

Calsamiglia, S., M. Busquet, P.W. Cardoso, L. Castillejos, and A. Ferret. 2007. Invited Review: Essential oils as modifiers of rumen microbial fermentation. J. Dairy Sci. 90:25802595.

Chaves, A.V., K. Stanford, L.L. Gibson, T.A. McAllister, and C. Benchaar. 2008. Effects of carvacrol and cinnamaldehyde on intake, rumen fermentation, growth performance, and carcass characteristics of growing lambs. Anim. Feed Sci. Technol. 145:396-408.
Cieslak A., M. Szumacher-Strabel , A. Stochmal, and W. Oleszek. 2013. Plant components with specific activities against rumen methanogens. Animal 7(s2):253-265.

Early, D.M., and F.D. Provenza. 1998. Food flavour and nutritional characteristics alter dynamics of food preference in lambs. J. Dairy Sci. 76:728-734.

Favreau-Peigne, A., R. Baumont, and C. Ginane. 2013. Food sensory characteristics: their unconsidered roles in the feeding behaviour of domestic ruminants. Animal 7(5):806-813.

Hristov, A.N., C. Lee, T. Cassidy, K. Heyler, J.A. Tekippe, G.A. Varga, et al. 2013. Effect of Origanum vulgare L. leaves on rumen fermentation, production, and milk fatty acid composition in lactating dairy cows. J. Dairy Sci. 96:1189-1202.

Jouany J.P., and D.P. Morgavi. 2007. Use of 'natural' products as alternatives to antibiotic feed additives in ruminant production. Animal 1(10):1443-1466.

Lan, R.X., T.S. Li, and I.H. Kim. 2016. Effects of essential oils supplementation in different nutrient densities on growth performance, nutrient digestibility, blood characteristics and fecal microbial shedding in weaning pigs. Anim. Feed Sci. Technol. 214:77-85

Marble, V. 1984. A new system for determining alfalfa hay quality: acid detergent fibre [online]. University of California, Alfalfa \& Forages. Available at: http://alfalfa.ucdavis. edu/+symposium/proceedings/1984/84-22. pdf. [Accessed December 27, 2012].

Marble, V. 1984. A new system for determining alfalfa hay quality: acid detergent fibre [online]. University of California, Alfalfa \& Forages. Available at: http://alfalfa.ucdavis. edu/+symposium/proceedings/1984/84-22. pdf. [Accessed December 27, 2012].

NRC. 1981. Nutrient requirements of goats: angora, dairy, and meat goats in temperate and tropical countries. Number 15. p. 2-53. National Research Council (NRC), National Academy Press, Washington D.C., USA.

Official Journal of the European Union. 2003. EU regulation no. 1831/2003 of the European Parliament and of the Council of 22 September 2003. Official Journal of the European Union L268:1-29.

Pacheco, D., and G.C. Waghorn. 2008. Dietary nitrogen - definitions, digestion, excretion and consequences of excess for grazing ruminants. Proceedings of the New Zealand Grassland Association 70:107-116 
Pirgozliev V., D. Bravo, M.W. Mirza, and S.P. Rose. 2015. Growth performance and endogenous losses of broilers fed wheatbased diets with and without essential oils and xylanase supplementation. Poultry Sci. 94:1227-1232.

Provenza, F. 1996. Acquired aversions as the basis for varied diets of ruminants foraging on rangelands. J. Dairy Sc. 74:2010-2020.

Rolls, B. J. 1986. Sensory specific satiety. Nutr. Rev. 44:93-101.

SAS. 1999. The SAS® system for Windows [cdrom]. Ver. 8. SAS Institute, Cary, North Carolina, USA.

Simitzis, P., S.G. Deligeorgis, J.A. Bizelis, A. Dardamani, I. Theodosiu, and K. Fegeros. 2008. Effect of dietary oregano oil supplementation on lamb meat characteristics. Meat Science 79:217-223.

Spanghero, C., C. Zanfi, E. Fabbro, N. Scicutella, and C. Camellini. 2008. Effects of a blend of essential oils on some end products of in vitro rumen fermentation. Anim. Feed Sci. Technol. 145:364-379.
Tedeschi, L.O., T.R. Callaway, J.P. Muir, and R.C. Anderson. 2011. Potential environmental benefits of feed additives and other strategies for ruminant production Rev. Bras. Zootec. 40(Supl. especial):291-309

Tsiplakou, E., M.A.M. Abdullah, D. Skliros, M. Chatzikonstantinou, E. Flemetakis, N. La brou, et al. 2017. The effect of dietary Chlorella vulgaris supplementation on micro-organism community, enzyme activities and fatty acid profile in the rumen liquid of goats. J. Anim. Physiol. Anim. Nutr. 101:275-283.

Van Keulen, J., and B.A. Young. 1977. Evaluation of acid-insoluble ash as a natural marker in ruminant digestibility studies. J. Anim. Sci. 44(2):282-287.

Van Soest, P.J., J.B Robertson, and B.A Lewis. 1991. Methods for dietary fibre, neutral detergent fibre, and non-starch polysaccharides in relation to animal nutrition. J. Dairy Sc. 74:3583-3597. 